The role of performance measurement in aligning operations with strategy: Sustaining cognitive processes of internal alignment

\author{
Andrea Bellisario \\ Faculty of Economics and Business \\ University of Groningen, The Netherlands \\ a.bellisario@rug.nl \\ +31503633535 \\ Andrey Pavlov* \\ Cranfield School of Management \\ Cranfield University, United Kingdom \\ andrey.pavlov@cranfield.ac.uk \\ +44 (0) $1234750111 \times 3104$ \\ Martijn van der Steen \\ Faculty of Economics and Business \\ University of Groningen, The Netherlands \\ m.p.van.der.steen@rug.nl \\ +31503633993
}

* Corresponding author 


\title{
The role of performance measurement in aligning operations with strategy: Sustaining cognitive processes of internal alignment
}

\begin{abstract}
Purpose: This paper addresses an important theoretical shortcoming in the conceptualization of internal alignment by investigating the cognitive processes involved in aligning operations with strategy and the role of performance measurement (PM) in sustaining these processes.

Design/methodology/approach: A theory-building study investigates the process of using PM to drive the implementation of a new strategy in a large beer manufacturer in Italy. The study employs a sensemaking perspective to theorize the findings. Data were collected through semistructured interviews, field observations, and company documents.

Findings: This study develops a theoretical model suggesting that establishing and maintaining internal alignment occurs through seeking, assembling, adjusting, and finalizing the meaning of how strategic priorities inform local action. PM plays a central role in this process by providing interpretive support.

Research implications: This article advances a cognition-centered view of internal alignment that complements the behavioral aspect of the phenomenon emphasized in prior literature.

Practical implications: Using PM for aligning operations with strategy is a complex and iterative process that requires time and effort and generates temporary stability. Managers may need to complement traditional approaches to alignment with providing space for sensemaking.

Originality/value: The paper proposes a view of internal alignment as an ongoing interpretive process that is sustained by PM. This process brings about the consistency of meanings that generates strategy-consistent behaviors.
\end{abstract}




\section{Introduction}

Connecting strategic objectives with operations has been an enduring theme in the operations management literature, and performance measurement (PM) has been recognized as a key element in establishing and maintaining this connection (Melnyk et al., 2010; 2014; Micheli and Manzoni, 2010; Nudurupati et al., 2021). Concerned with how PM can support strategy implementation, this literature has argued that PM systems are important means available to managers to establish internal alignment - i.e., to ensure that behaviours in the organization can be directed towards achieving strategic objectives. Over the past two decades, the literature on PM and strategy implementation (e.g., Kaplan and Norton, 2006; Micheli et al., 2011; Micheli and Mura, 2017; Smith and Bititci, 2017; Lucianetti et al., 2019; Abernethy et al., 2021) has described how organizations can create internal alignment through the design and use of performance indicators and PM systems.

However, despite this progress, explanations of the cognitive aspects of internal alignment remain scarce. In this paper, we argue that the existing PM literature lacks an explicit theorization of the role of cognition in establishing and maintaining internal alignment and that such theorization is necessary for obtaining a fuller understanding of the functionality of PM (see: Merchant and Otley, 2020). This theoretical oversight is addressed in this paper.

The role of cognition in internal alignment has often been acknowledged by PM scholars - both in conceptual (e.g., Ferreira and Otley, 2009; Broadbent and Laughlin, 2009) and empirical (e.g., Bititci et al., 2011; Mirzaei et al., 2016) studies - as being important for aligning operations with strategy. These studies have particularly claimed that interpretive processes involved in identifying the drivers of organizational success can affect, and be affected by, the way PM is employed in the organization, both by managers and by the shop floor staff. However, these studies stop short of theorizing these interpretive processes explicitly, treating cognition mostly as taken-for-granted. In this paper, we explore internal alignment from the cognitive perspective to explain the influence of PM on people's individual and collective understanding of the link between strategy and operations - their grasp of how strategic priorities should inform shop floor actions. Researchers (e.g., Franco-Santos and Otley, 2018; Merchant and Otley, 2020) have recently called attention to this perspective, emphasizing its potential for generating better explanations of how people in organizations engage with PM in the process of implementing strategy and aligning local actions with strategic priorities. 
We draw on the theory of sensemaking (Weick et al., 2005) and conduct a theorybuilding (Eisenhardt and Graebner, 2007) study that explores the process of establishing internal alignment following the introduction of a new strategy and a corresponding set of performance indicators in an Italian beer manufacturer's production plant. The study contributes to the literature by developing a theoretical model that details how internal alignment develops through cognitive processing. The model explains how people's engagement with PM generates and refines local meanings, facilitating the translation of strategic objectives into corresponding local actions. More specifically, the model highlights four cognitive processes (seeking, assembling, adjusting, and finalizing) that create the consistency of meaning necessary for bringing local action in line with strategic objectives.

The paper follows a standard structure. To improve readability, the terms 'internal alignment' and 'alignment' are used interchangeably.

\section{Theoretical Background}

\subsection{PM, strategy implementation and internal alignment}

The notion of alignment plays a central role in the research investigating the role of PM in strategy implementation (McAdam et al., 2017). Comprehensive conceptual frameworks have theorized alignment as a phenomenon that includes both cognitive and behavioural aspects and performs a critical management control function within the organization (e.g., Ferreira and Otley, 2009; Broadbent and Laughlin, 2009; Merchant and Otley, 2020). Put differently, alignment refers to the consistency in people's understandings and behaviours across organizational levels, which is necessary for realizing the overall strategic intent at the operational level. For example, Ferreira and Otley (2009) suggest that an active involvement of the lower echelon in the process of implementing strategy through PM "is likely to result in greater understanding [of] the strategic intent, acceptance of the path to be undertaken and, importantly, provide for broader organizational alignment” (p. 270).

However, most research investigating the use of PM in implementing strategy has focused on the behavioural aspect of alignment, examining how actions could be brought in line with strategic objectives via PM. Much of this work has centred on the use of performance indicators and targets to drive strategy-consistent behaviours, as strategic objectives are set up and deployed (e.g., Bourne, 2002; Kaplan and Norton, 2006; Melnyk et al., 2014; Smith and Bititici, 2017; Bititci et al., 2018; Lucianetti et al., 2019; Abernethy et al., 2021). This work 
mostly presumes that actions can be made compliant with strategic objectives through the design and use of PM systems. For example, investigating the deployment of strategic objectives, Hanson et al. (2011) showed that by disaggregating and decomposing strategic performance indicators (i.e., specifying the organizational functions implicated in these indicators and listing the corresponding functional activities), behaviours at the operational level could be directed towards strategic objectives, thus creating internal alignment. Micheli and Mura (2017) reached similar conclusions, noting that "there is a wide recognition that a carefully designed PM [system] could induce strategy-consistent behaviour” (p. 425).

This emphasis on the behavioural aspect of alignment has meant that the cognitive aspect - i.e., the consistency in the understanding and interpretation of strategic objectives remained somewhat neglected. Some progress in this area has been made by management accounting scholars (e.g., Hall, 2010; Groen et al., 2012), but most of their work has focused on individual cognition, for example investigating the relationship between PM, the experienced meaningfulness of work, and individual performance. Thus, this stream of research has avoided an explicit focus on alignment as an organizational means of connecting operations with strategy. On the other hand, studies that have acknowledged the importance of understanding the cognitive aspect of alignment at the organizational level (e.g., Bititci et al., 2011; Chenhall et al, 2013; Mirzaei et al., 2016), have tended to treat it in very general terms or leave it undertheorized. For example, studying cognition in the process of arriving at a consistent view of strategic objectives in the organization, Chenhall et al. (2013) described it broadly as 'creative discussions' without explaining the dynamics that generate such discussions or illustrating their outcomes (see also Wouters and Wilderom, 2008; Jordan and Messner, 2012; Pellinen et al., 2016 for similar discussions). Others have turned to alternative terminology such as "strategy consensus" (Mirzaei et al., 2016) or "employee perceptions" (de Menezes and Escrig, 2019). However, these contributions stop short of providing a significant theoretical insight into how cognition is implicated in, and contributes to, the generation of alignment. Recent contributions to the field do not seem to address this theoretical oversight. For instance, Nudurupati et al. (2021) argue that strategic objectives can be deployed and acted upon by shop floor teams through 'interactive dialogue'; yet, their study remains silent on how such dialogue can emerge, unfold and be conducive to alignment.

On the other hand, the recent literature on the unintended consequences of PM (e.g., Gray et al., 2014; Muller, 2017; Franco-Santos and Otley, 2018) has explicitly highlighted the paradox where "technically" aligned PM systems, aiming to ensure desired behaviours across 
the organization, can "misfire" when they fail to align people's cognitions as well, thus potentially resulting in inappropriate behaviours and a weakening of alignment (e.g., Chenhall and Euske, 2007). Franco-Santos and Otley (2018), for example, noted that excessive focus on aligning behaviours can alter "the existing social relationships that shape individual decisions" (p. 697), and Merchant and Otley (2020) have recently argued that PM systems' functionality should be understood according to how people in organizations think and learn to adapt their behaviours to strategies.

Considering the above, we argue that existing PM literature lacks a sufficient understanding of the cognitive aspect of alignment, and that this crucial PM concept remains under-researched and under-theorized. In this paper, we therefore aim to investigate the cognitive processes that are mobilized when PM is used for strategy implementation within an organization, thus advancing a theoretical view of the aspect of alignment that has been systematically overlooked. Formally, our study is guided by the following research question: How does PM sustain cognitive processes of internal alignment?

\subsection{Theoretical framing}

An examination of the cognitive aspect of alignment that is facilitated by PM during strategy implementation requires a theoretical perspective that emphasises cognition. Accordingly, we have adopted a sensemaking perspective to capture the ways in which strategic objectives are interpreted and consistency in interpretation and understanding emerges (Patriotta, 2003; Maitlis and Sonenshein, 2010). Research in PM has called for investigating the cognitive foundations of forming a system-wide approach to managing organizations (Bititci et al., 2011), and sensemaking has been shown to be a useful perspective for investigating PM-related phenomena more specifically. For instance, Dahler-Larsen (2014) argued that performance indicators can be seen as "form of assisted sense-making that offer interpretive keys which draw attention, define discourse and orient actions in certain directions" (p. 976).

Sensemaking is a major perspective in management studies that grew out of the work of Weick $(1988 ; 1995)$ and has had a major effect on a variety of management disciplines (Sandberg and Tsoukas, 2015). Essentially, sensemaking describes a process of organizing, whereby people cope with disruptive changes in their circumstances by discovering the nature of the changed reality through acting and interpreting the effects of their actions (Weick et al., 2005). Sensemaking helps new circumstances to be "turned into a situation that is 
comprehended explicitly in words and that serves as a springboard to action" (Taylor and Van Every, 2000 cited in Weick et al., 2005, p. 409). Through this process, people bring order into the ways they experience organizational changes.

At its core, sensemaking helps answer two questions: "What's going on here?" and "What do I do next?" (Weick et al., 2005). The answer to the first question comes as people notice something unexpected in their environment. Weick (1995) refers to these events as cues. What is extracted as a cue is personal and depends on the context, and some potential cues are never picked up as such (Maitlis, 2005). The second question, however, is answered as cues are interpreted and plausible meanings are generated, so that some degree of sense is restored, and meaningful action becomes possible again (Rerup and Feldman, 2011). This process relies on interaction with others and is therefore inherently social (Maitlis and Christianson, 2014).

Although there have been multiple attempts to describe sensemaking systematically, Weick et al. (2005) develop a generic structure of the sensemaking process that captures its full scope and allows it to be applied in multiple contexts. We draw on this structure in our study because it specifically tends to the processes through which organizational members make sense of organizational changes such as the introduction of new strategic objectives. This sensemaking structure describes four elements of the sensemaking process.

Sensemaking begins with an ecological change - a change in the perceiver's circumstances. For a manager performing a set role, this could be a change in the organization's strategy, a disruption in the way of working, or a similar event. Second, people begin to detect that priorities shift, old actions fail to deliver the expected results, and the usual order is unsettled. They begin to define specific cues - events and issues - in this unusual new reality through the process of enactment. Enactment comprises two specific processes: noticing (spotting unusual occurrences) and bracketing (binding them into a discrete cue). Third, the possible meanings of the new cues are interpreted and discussed with others, eventually being reduced to what is plausible and actionable. This takes place through the process of selection. Finally, with time, the selected meanings gain substance and solidity through the process of retention, during which the newly forged meanings become the accepted basis for action. Thus, Weick et al.'s (2005) structure describes how sensemaking restores meaning, and to some extent order, following a disruption.

The sensemaking perspective thus provides a suitable approach to investigating the cognitive foundations of aligning strategic objectives with operations, leading us to adopt it as 
a theoretical lens for understanding the cognitive side of the process through which alignment is established.

\section{Research design and methods}

\subsection{Research strategy and case context}

The research strategy was informed by a need to ensure methodological fit (Edmondson and McManus, 2007), which constitutes internal consistency between the state of theoretical development of the phenomenon, the research question and the design and envisaged contributions of the study. Phenomena supported by mature theories and accepted constructs lend themselves to hypothesis-driven research and quantitative data analysis. In contrast, phenomena at the nascent stage of theory development require inductive, theory-building research designs and qualitative data whose meaning needs to be interpreted. The paucity of studies investigating the cognitive aspect of alignment, the "lack of overarching theory in the area to guide alignment studies" (McAdam et al., 2017, pg. 7169), and the resulting lack of a good theoretical understanding of the role of PM in cognitive processes of alignment placed our study into the latter category.

Therefore, our study was designed as a theory-building one, investigating a single case in-depth (Ketokivi and Choi, 2014) and drawing on qualitative data, which are particularly "appropriate for exploratory endeavors to stimulate new theoretical ideas" (Edmondson and McManus, 2007, p. 1156). This design enabled us to interpret meanings of organizational events and actions as they were experienced by organizational actors (Eisenhardt and Graebner, 2007) and generate new constructs for theorizing the role of PM in the cognitive processes of alignment.

Consistent with the principle of theoretical sampling (Eisenhardt and Graebner, 2007), we selected a research site that was undergoing a strategy implementation process and relied on PM for establishing and maintaining alignment between strategic objectives and operations. We conducted the study in the Brewery (disguised for confidentiality), a major beer production plant of an Italian brewing company, which was a wholly owned subsidiary of one of the top global beverage manufacturers (HQ). The Brewery employed nearly 600 people and was organized into three departments - Brewing, Packaging, and Warehousing. It produced 17 types of bottled, canned and barrelled beer under several world-famous brands for wholesale distributors, with a batch production volume of 4.8 million hectolitres per year. 
At the time of the study, HQ was implementing a new strategy, 'The Manufacturing Principle' (disguised for confidentiality), aiming to improve competitiveness in international markets. It included four strategic priorities: developing a portfolio of strong brands; pursuing sustainable profitability; strong presence of brands in the market; and leveraging plant-level skills worldwide. This strategy was formulated and driven from the top and communicated to every subsidiary through Super KPIs - a set of high-level performance indicators and corresponding targets that aimed to capture the entirety of corporate strategy adapted for specific context and priorities.

The worldwide rollout of this strategy spanned several years and included four phases: Pre-launch Preparation, which involved global planning and high-level training; Development, where corporate plans were translated into Super KPIs for each subsidiary; Implementation, where plants made operational changes to align operations with Super KPIs; and Entrenchment, where lessons were drawn and used for further improvements. Consistent with our focus on alignment, we conducted the study during the Implementation phase. The timing of it was different in different subsidiaries - in the Brewery, it started in 2013 and took place between 2014 and 2016.

For the Brewery, the new strategy represented a significant shift in direction. Whereas it had traditionally focused on product quality, the new strategy also brought with it a strong emphasis on efficiency and sustainability. These were new objectives generating significant disruptions in the old ways of working. In total, HQ introduced nine Super KPIs to the Brewery. These are presented in Table 1 below, mapped against the corporate strategic objectives.

The implementation of strategy was thus explicitly driven by PM. To support this, the Brewery introduced weekly Short Interval Control (SIC) meetings, where the staff reviewed local performance data against the Super KPIs and proposed corrective actions. SIC meetings thus helped to ensure that changes in operations introduced in pursuit of alignment were made in constant reference to performance objectives.

\subsection{Data collection}

Data collection began in 2014 with two exploratory interviews (approximately 3 hours in total) with the plant manager and the manufacturing development manager, both of whom supervised all PM activities in the Brewery. The aim of these interviews was to understand the implications of the strategic priorities captured in the Super KPIs for the Brewery operations. 
Table 1. The Super KPIs

\begin{tabular}{|c|c|c|c|c|}
\hline Title of KPIs & Description & Department & Plant-level performance targets & $\begin{array}{l}\text { Corresponding strategic priority } \\
\text { from } \mathrm{HQ}^{1}\end{array}$ \\
\hline $\begin{array}{l}\text { 1) Beer foam } \\
\text { duration }\end{array}$ & $\begin{array}{l}\text { Newly introduced product } \\
\text { quality indicator. }\end{array}$ & Brewing & $>247$ seconds & $\begin{array}{l}\text { Developing a portfolio of strong } \\
\text { brands. }\end{array}$ \\
\hline 2) Beer brightness & $\begin{array}{l}\text { Newly introduced product } \\
\text { quality indicator. }\end{array}$ & Brewing & $\mathrm{MEL}^{2}<5.98 \%$ & $\begin{array}{l}\text { Developing a portfolio of strong } \\
\text { brands. }\end{array}$ \\
\hline $\begin{array}{l}\text { 3) Dissolved oxygen } \\
\text { in beer }\end{array}$ & $\begin{array}{l}\text { Existing product quality } \\
\text { indicator for beer packaged in } \\
\text { barrels. Its adoption was } \\
\text { extended to all the beer formats } \\
\text { packaged in the plant, including } \\
\text { cans and bottles, with a revised } \\
\text { target. }\end{array}$ & $\begin{array}{l}\text { Brewing/ } \\
\text { Packaging }\end{array}$ & Dissolved Oxygen $<44 \mathrm{ppb}^{3}$ & $\begin{array}{l}\text { Developing a portfolio of strong } \\
\text { brands. }\end{array}$ \\
\hline $\begin{array}{l}\text { 4) Water } \\
\text { consumption }\end{array}$ & $\begin{array}{l}\text { Newly introduced process } \\
\text { efficiency indicator. }\end{array}$ & $\begin{array}{l}\text { Brewing/ } \\
\text { Packaging }\end{array}$ & $\begin{array}{c}<3.22 \text { hectolitres per hectolitre } \\
\text { of produced beer }\end{array}$ & Pursuing sustainable profitability. \\
\hline $\begin{array}{l}\text { 5) Electricity } \\
\text { consumption }\end{array}$ & $\begin{array}{l}\text { Newly introduced process } \\
\text { efficiency indicator. }\end{array}$ & $\begin{array}{l}\text { Brewing / } \\
\text { Packaging }\end{array}$ & $\begin{array}{c}<6.44 \mathrm{KW} / \mathrm{h} \text { per hectolitre } \\
\text { produced and packaged }\end{array}$ & Pursuing sustainable profitability. \\
\hline $\begin{array}{l}\text { 6) Equipment } \\
\text { efficiency }\end{array}$ & $\begin{array}{l}\text { Existing process efficiency } \\
\text { indicator. The target was } \\
\text { unchanged but the use was } \\
\text { extended to the brewing } \\
\text { department. }\end{array}$ & $\begin{array}{l}\text { Brewing / } \\
\text { Packaging }\end{array}$ & $\mathrm{OEE}^{4}>85 \%$ & $\begin{array}{l}\text { Developing a portfolio of strong } \\
\text { brands. Pursuing sustainable } \\
\text { profitability. Strong presence of } \\
\text { brands in the market. }\end{array}$ \\
\hline 7) Completed items & $\begin{array}{l}\text { Existing process efficiency } \\
\text { indicator. The target was }\end{array}$ & Packaging & $\begin{array}{c}\text { Items completed }>89.75 \% \text { of } \\
\text { items started }\end{array}$ & $\begin{array}{c}\text { Strong presence of brands in the } \\
\text { market. }\end{array}$ \\
\hline
\end{tabular}

${ }^{1}$ The strategic priority of "Leveraging plant-level skills worldwide" was a corporate-level objective and so did not have a specific Super KPI attached to it at the plant level.

${ }^{2}$ MEL: chemical measure, expressed in percentage, for the concentration of wort proteins determining the density of beer.

${ }^{3} \mathrm{ppb}$ : 'parts per billion': number of mass units of oxygen per 1000 million mass units of beer.

${ }^{4}$ OEE: 'overall equipment efficiency', measured as the ratio of fully productive time to total productive time of production lines. 
stretched and made uniform for

all the formats packaged.

\begin{tabular}{|c|c|c|c|c|}
\hline 8) Time in depot & $\begin{array}{l}\text { Newly introduced process } \\
\text { efficiency indicator for } \\
\text { minimizing storage of finished } \\
\text { batches in the warehouse. }\end{array}$ & Warehousing & $68 \mathrm{~min}$ & $\begin{array}{l}\text { Strong presence of brands in the } \\
\text { market. }\end{array}$ \\
\hline $\begin{array}{l}\text { 9) Safety of } \\
\text { operations }\end{array}$ & $\begin{array}{l}\text { Existing safety indicator. The } \\
\text { content and targets were } \\
\text { detailed for each production } \\
\text { department. }\end{array}$ & $\begin{array}{c}\text { Brewing / } \\
\text { Packaging / } \\
\text { Warehousing }\end{array}$ & $\begin{array}{c}\text { Near miss } 5 \text { : brewing }<5 ; \\
\text { packaging }<7 \text {; warehousing }<4\end{array}$ & Pursuing sustainable profitability. \\
\hline
\end{tabular}

${ }^{5}$ Near miss: number of reportedly unexpected events that, once happened, might have potential to cause injuries 
Main data were collected between July 2015 and May 2016 and involved 42 recorded semi-structured interviews with departmental managers and operational staff ( 34 hours in total) and 26 hours of dedicated site visits (Table 2). The interviewees included key informants across multiple organizational levels (Figure 1). We asked to be introduced to, and interviewed, people playing a critical role in aligning shop floor operations with the new Super KPIs. Data collection was arranged in two phases and driven by the data saturation criterion (Miles and Huberman, 1994).

Table 2. Details of data collection

\section{Interviews}

\begin{tabular}{|c|c|c|}
\hline Job Title & Responsibilities & Interview length and period \\
\hline 1) Plant Manager & $\begin{array}{l}\text { General direction of the } \\
\text { plant. }\end{array}$ & $\begin{array}{c}\text { i) } 1 \mathrm{~h} .- \text { July } 2015 \\
\text { ii) } 1 \mathrm{~h} \text { and } 18 \text { min. }- \text { March } 2016\end{array}$ \\
\hline $\begin{array}{l}\text { 2) Manufacturing Development } \\
\text { Manager }\end{array}$ & $\begin{array}{l}\text { Implementation of people's } \\
\text { process improvement } \\
\text { practices in the plant. }\end{array}$ & $\begin{array}{l}\text { i) } 40 \text { min. - July } 2015 \\
\text { ii) } 1 \text { h and } 08 \text { min. - May } 2016\end{array}$ \\
\hline 3) Brew Manager & $\begin{array}{l}\text { General direction of the } \\
\text { brewing department. Head } \\
\text { of the brewing production } \\
\text { planning in the plant. }\end{array}$ & $\begin{array}{l}\text { i) } 40 \mathrm{~min} \text {. - July } 2015 \\
\text { ii) } 1 \mathrm{~h} \text { and } 14 \mathrm{~min} \text { - January } 2016 \\
\text { iii) } 20 \mathrm{~min} \text { - - May } 2016\end{array}$ \\
\hline 4) Packaging Manager & $\begin{array}{l}\text { General direction of the } \\
\text { packaging department. }\end{array}$ & $\begin{array}{l}\text { i) } 30 \mathrm{~min} \text {. - July } 2015 \\
\text { ii) } 1 \mathrm{~h} \text { and } 09 \mathrm{~min} \text {. - October } 2015 \\
\text { iii) } 22 \mathrm{~min} \text {. - April } 2016\end{array}$ \\
\hline 5) Warehousing Manager & $\begin{array}{l}\text { General direction of the } \\
\text { warehousing department, } \\
\text { and inbound logistics. }\end{array}$ & $\begin{array}{l}\text { i) } 30 \mathrm{~min} \text {. - July } 2015 \\
\text { ii) } 1 \mathrm{~h} \text { and } 15 \mathrm{~min} \text {. - January } 2016 \\
\text { iii) } 1 \mathrm{~h} \text { and } 21 \mathrm{~min} \text {. - April } 2016\end{array}$ \\
\hline $\begin{array}{l}\text { 6) Plant Quality Assurance } \\
\text { Manager }\end{array}$ & $\begin{array}{l}\text { External quality assurance } \\
\text { for the plant. }\end{array}$ & i) 58 min. - July 2015 \\
\hline 7) Plant Technical Manager & $\begin{array}{l}\text { Optimization processes of } \\
\text { plant equipment. }\end{array}$ & $\begin{array}{l}\text { i) } 1 \mathrm{~h} \text { and } 10 \mathrm{~min} \text {. - July } 2015 \\
\text { ii) } 45 \mathrm{~min} .- \text { May } 2016\end{array}$ \\
\hline 8) Plant Laboratory Technician & Beer quality control. & i) $1 \mathrm{~h}$ and 15 min. - April 2016 \\
\hline 9) Controller & $\begin{array}{l}\text { Plant-level and } \\
\text { departmental cost } \\
\text { accounting. }\end{array}$ & $\begin{array}{l}\text { i) } 1 \mathrm{~h} \text { and } 10 \text { min. - July } 2015 \\
\text { ii) } 30 \mathrm{~min} .- \text { September } 2015\end{array}$ \\
\hline 10) Plant Buyer & Sourcing of raw materials. & i) 45 min. - March 2016 \\
\hline $\begin{array}{l}\text { 11) Maintenance Supervisor - } \\
\text { Packaging }\end{array}$ & $\begin{array}{l}\text { Maintenance activities in } \\
\text { the department. }\end{array}$ & $\begin{array}{l}\text { i) } 45 \mathrm{~min} \text {. - July } 2015 \\
\text { ii) } 1 \mathrm{~h} \text { and } 04 \mathrm{~min} \text {. - March } 2016 \\
\text { iii) } 20 \mathrm{~min} \text { - - May } 2016\end{array}$ \\
\hline 12) Plant Packaging Planner & $\begin{array}{l}\text { Coordination of the } \\
\text { production planning in the } \\
\text { department. }\end{array}$ & i) 58 min. - April 2016 \\
\hline 13) Plant Energy Supervisor & Energy optimization. & i) 57 min. - July 2015 \\
\hline 14) Brewing Technical Supervisor & $\begin{array}{l}\text { Supervision of brewing } \\
\text { operations. }\end{array}$ & $\begin{array}{l}\text { i) } 33 \text { min. - January } 2016 \\
\text { ii) } 1 \mathrm{~h} \text { and } 06 \text { min. - April } 2016\end{array}$ \\
\hline $\begin{array}{l}\text { 15) Line Performance Supervisor - } \\
\text { Packaging }\end{array}$ & $\begin{array}{l}\text { Supervision of packaging } \\
\text { technical operations. }\end{array}$ & $\begin{array}{l}\text { i) } 49 \text { min. - July } 2015 \\
\text { ii) } 1 \mathrm{~h} \text { - April } 2016\end{array}$ \\
\hline
\end{tabular}


16) Maintenance Planner -

Brewing

17) Head of Packaging Operations

18) Head of Logistics Operations

19) Team Leader - Brewing

20) Brew Specialist

21) Team Leader - Packaging

22) Packaging Specialist

23) Logistics Specialist
Planning of maintenance.

Team coordination and allotment of orders by lines.

Coordination of shipping to clients.

Coordination of a brewing line team.

Operational support to brewing line staff.

Coordination of a packaging line team.

Operational support to packaging line staff.

Operational support to logistics staff. i) 40min. - July 2015

ii) $1 \mathrm{~h}$ - March 2016

i) 48 min. - July 2015

ii) $1 \mathrm{~h}$ and $18 \mathrm{~min}$ - April 2016

i) 52 min. - July 2015

ii) $1 \mathrm{~h}$ and $09 \mathrm{~min}$. - January 2016

i) 20 min. - March 2016

ii) 40 min. - May 2016

i) $32 \mathrm{~min}$ - May 2016

i) 35 min. - March 2016

ii) 44 min. - May 2016

i) 34 min. - May 2016

i) 25 min. - April 2016

Total Time $=34$ hrs. $12 \mathrm{~min}$.

Site visits and observations

\begin{tabular}{|c|c|c|}
\hline Type of visit/observation & Data & Time spent on-site \\
\hline $\begin{array}{l}\text { Two initial on-site visits involving: } \\
\text { general tour of the plant; a meeting } \\
\text { with the plant manager and the } \\
\text { manufacturing development } \\
\text { manager. }\end{array}$ & $\begin{array}{c}\text { Notes; } 2 \text { exploratory interviews } \\
\text { recorded. }\end{array}$ & $6 \mathrm{hrs}$ (including $3 \mathrm{hrs}$ of interviews) \\
\hline Attending three SIC meetings. & $\begin{array}{l}\text { Recorded dialogues; notes taken in } \\
\text { all the meetings. }\end{array}$ & 4 hrs. \\
\hline $\begin{array}{l}\text { Attending four continuous } \\
\text { improvement sessions between } \\
\text { dept. managers and line-staff. }\end{array}$ & $\begin{array}{l}\text { Recorded dialogues in two } \\
\text { meetings; notes taken in all the } \\
\text { meetings. }\end{array}$ & 4 hrs. \\
\hline $\begin{array}{l}\text { Three on-site visits to review and } \\
\text { discuss with dept. managers the } \\
\text { relevant documentation concerning } \\
\text { PM. }\end{array}$ & $\begin{array}{l}\text { Recorded dialogues in one meeting; } \\
\text { notes taken during the discussions. }\end{array}$ & 12 hrs. \\
\hline
\end{tabular}

Total Time $=26 \mathrm{hrs}$. 
Figure 1. Organizational chart: interviewees

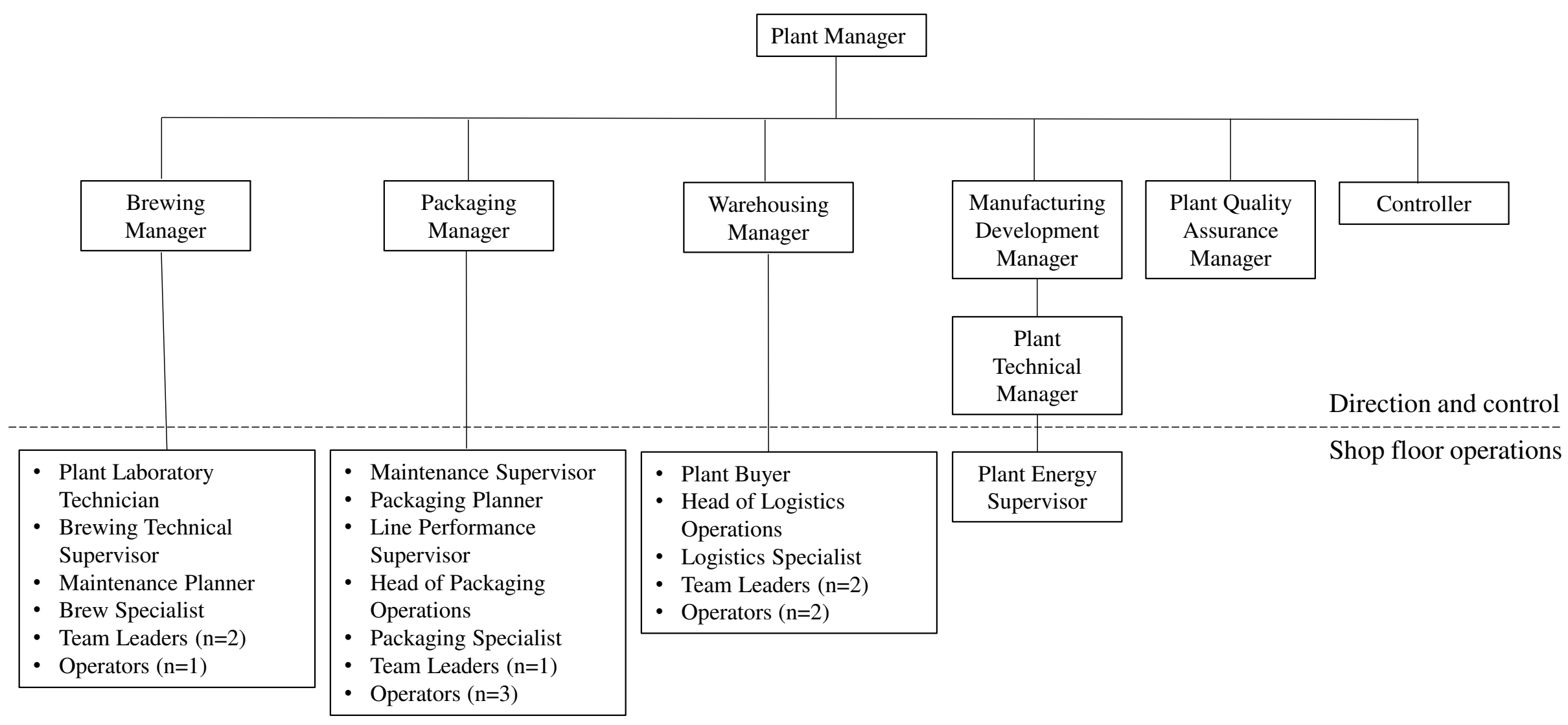


First, between July 2015 and March 2016, we conducted the interviews. The questions focused on the design and use of operational performance indicators to ensure the alignment of shop floor operations with Super KPI targets [1]. Where possible, people were interviewed more than once to improve reliability. The interviews generated detailed accounts of various ways in which people employed PM during the implementation of the Super KPIs. In addition, we observed a total of 12 meetings between departmental managers and shop floor staff, as well as among managers. A total of three working days were additionally spent with the managers to review relevant documentation concerning the adoption of PM systems. Detailed notes were kept for all meetings.

Second, in April and May 2016, we returned to the site to validate the conclusions from the initial analysis with the respondents.

\subsection{Data analysis}

All interviews were transcribed verbatim and analyzed as primary data sources (Robson, 2011) using NVivo. Consistent with the theory-building nature of the study, data analysis procedures followed the Gioia methodology (Gioia et al., 2012) - a structured approach to analyse data for theory-building that is particularly suited to "how people understand the changes they are both instigating and dealing with, and how those meanings evolve" (Langley and Abdallah, 2011, p. 231). This approach has been widely used in sensemaking studies (Corley and Gioia, 2004), including applications to PM (Micheli and Pavlov, 2017; Beer and Micheli, 2017). It involves building a data structure through a sequence of three steps. First, researchers engage in open coding, identifying informant-centric categories close to the original data. In our analysis, this step generated fourteen first-order codes, each representing a distinct performance measurement and management practice that supported sensemaking activities at the Brewery. The second step involves identifying relationships between first-order codes, and grouping them into theoretically meaningful second-order themes. This step of our analysis produced eight second-order themes. Finally, through further abstraction, researchers arrive at a small number of concepts that become the building blocks of an emergent theoretical model. In our analysis, four such concepts represented the constituent elements of a cognition-centred model of internal organizational 
alignment. This process and the resulting data structure are illustrated in Figure 2 and supported by Table 3 .

The validation procedures included multiple rounds of data-to-codes matching, where one author performed the matching and the others independently checked the results, and continuous iterations between data and relevant literature for theoretical validity and identification of new theoretical concepts (Gioia et al., 2012). 
Figure 2. Data Structure

First-order codes

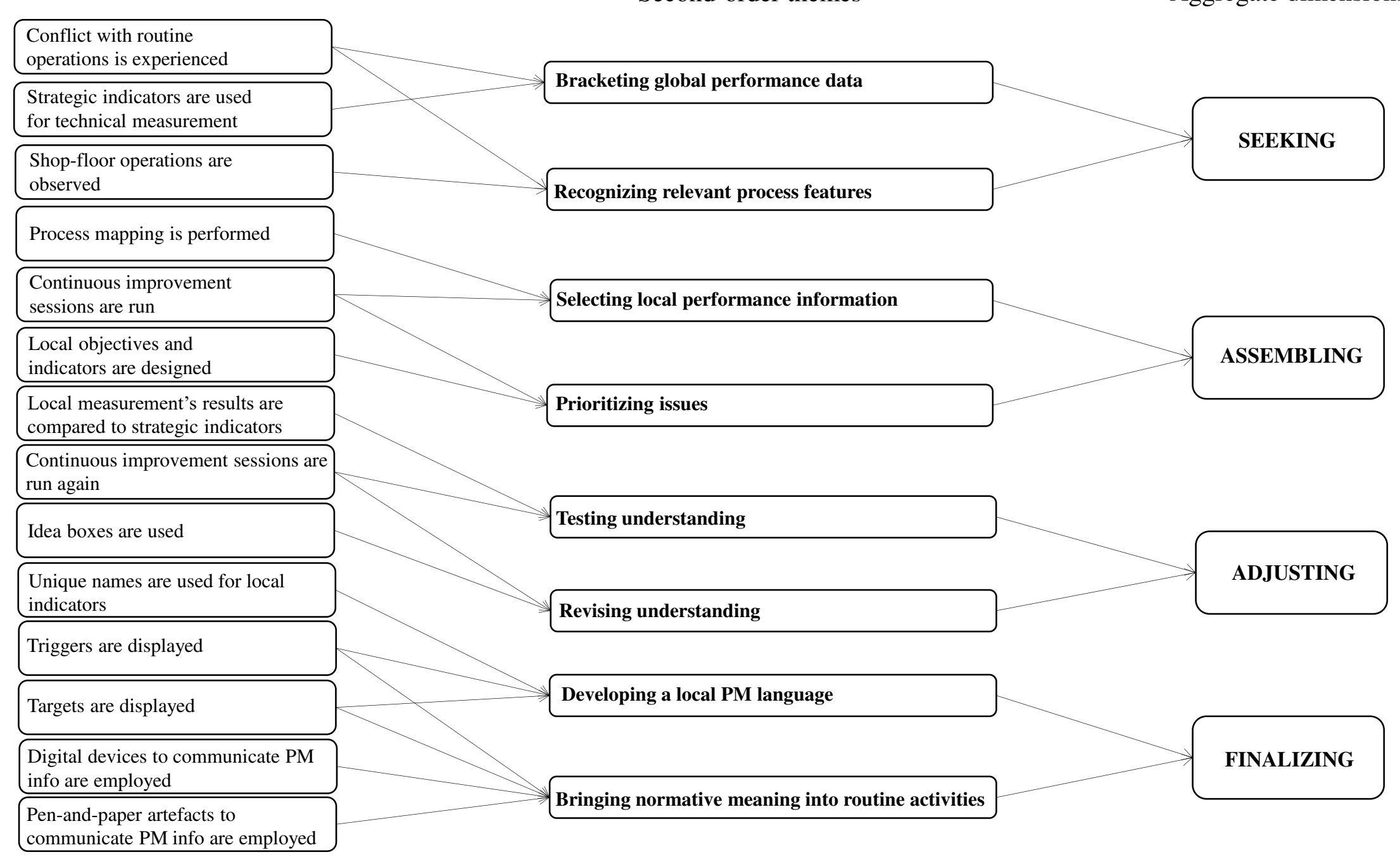


Table 3. Supporting evidence from interviews

\begin{tabular}{|c|c|}
\hline First-order codes & Supporting evidence from interviews \\
\hline $\begin{array}{l}\text { Conflict with routine } \\
\text { operations is } \\
\text { experienced }\end{array}$ & $\begin{array}{l}\text { - "Not a single way of doing my job looked the same to me (...) Maybe I have been a bit too pessimistic, but these Super KPIs implied actions I never } \\
\text { considered before in my operations." [Team leader - Brewing] } \\
\text { "As the 'Completed Items' target was changed, we started to experience line stops. We tried numerous quick fixes, but realized that our old knowledge } \\
\text { of the lines wasn't enough. We needed to think of something new." [Maintenance supervisor - Packaging] } \\
\text { "As soon as I heard about the 'Time in Depot' I thought: this is not going to happen with the operations we have in place (...) Time as a performance } \\
\text { objective looked obvious to achieve at first sight, but every time we started timing things in the warehouse, the usual argument was: 'I have always } \\
\text { done things this way, now why is it not working?" [Head of logistics operations - Warehousing] }\end{array}$ \\
\hline $\begin{array}{l}\text { Strategic indicators are } \\
\text { used for technical } \\
\text { measurement }\end{array}$ & $\begin{array}{l}\text { - "We were all discussing different percentages for the 'OEE' that we measured across multiple shifts. In my case, the results were not very good. But } \\
\text { I sensed that it depended on the pouring operations, which I flagged up as an issue." [Brewing technical supervisor] } \\
\text { "The daily measurement of 'Water Consumption' prompted me to talk about a few things (...) We got a slide projected in a pre-shift meeting where a } \\
\text { bar chart showed how [consumption] spikes alternated between morning and afternoon shifts, which made me point out that we were using the } \\
\text { supplementary rinsing unit in hall No. } 2 \text { during afternoons." [Head of Packaging operations] } \\
\text { "For the 'Electricity Consumption', Warehousing was the worst department in terms of results (...) The constant red flag raised during the pre-shift } \\
\text { discussions reminded me at some point of the lights that were always on in certain areas of the warehouse that we seldom used." [Plant energy } \\
\text { supervisor] }\end{array}$ \\
\hline $\begin{array}{l}\text { Shop floor operations } \\
\text { are observed }\end{array}$ & $\begin{array}{l}\text { - "At some point, to make it clear to myself what was actually affecting different levels of MEL percentage, I started observing how silos were cleaned } \\
\text { after brewing and made my personal hypotheses about whether these operations could, or couldn't, be a determinant of the new performance target." } \\
\text { [Brew manager - Brewing] } \\
\text { "I put on safety shoes and walked the shop-floor halls to match numbers with real problems. That's where ideas started to come along to manage the } \\
\text { implementation." [Plant manager] } \\
\text { "The new workstation layout that we have been using made me feel like I couldn't really get the grasp of what was going on with loading pallets. Our } \\
\text { warehouse operators were supposed to follow the Kanban signs on the floor as if these signs could magically streamline all the operations. The truth } \\
\text { is, I had to go and watch myself the forklifts in action to make up my mind about Kanban." [Warehousing manager] }\end{array}$ \\
\hline $\begin{array}{l}\text { Process mapping is } \\
\text { performed }\end{array}$ & $\begin{array}{l}\text { - "We usually map the transfer of beer from the vats to the packaging hall to spot those two to three critical aspects of performance that must be regularly } \\
\text { discussed in the pre-shift meetings" [Brew specialist - Brewing] } \\
\text { "In daily mapping sessions focusing on bottling machines, I noticed that changeovers between product formats surprisingly were not a problem. Rather, } \\
\text { bottles can break due to the speed of the conveyor belt. So, to nail the target of 'Finished Items' I instead focused on speed as a relevant [performance] } \\
\text { element, which became a priority in the department." [Packaging specialist] }\end{array}$ \\
\hline
\end{tabular}




\begin{tabular}{|c|c|}
\hline & $\begin{array}{l}\text { - "To understand why 'Time in Depot' was off target, I ran three VSM sessions. (...) I identified one crucial element that deserved further attention, in } \\
\text { my view, to hit the } 68 \text { min target. That was the throughput time in the handling areas of the warehouse, which we kept discussing in our meetings." } \\
\text { [Logistics specialist - Warehousing] }\end{array}$ \\
\hline $\begin{array}{l}\text { Continuous } \\
\text { improvement sessions } \\
\quad \text { are run }\end{array}$ & $\begin{array}{l}\text { - 'Using the PDCA wheel has become almost a game in my team. There not a single session where notes are not stuck on the poster and later removed } \\
\text { (...) For instance, the dispersion of heat from pipes, in one of our last sessions, came to focus (...) It was put and removed from the 'C', I believe, ten } \\
\text { times or so. This was actually an important topic long debated in the department, as some argued it would impact on 'Electricity Consumption', but } \\
\text { others argued that losing a bit of energy could still be normal." [Maintenance planner - Brewing] } \\
\text { "We invented the so-called 'top-five breakdown sessions', whereby we were able to locate the top five machines giving us major trouble over a week } \\
\text { (...) This week we are following three kegging lines because we noticed anomalies with the filling pressure. (...) There is still a bit of disagreement } \\
\text { on the possible effects that these pressure gaps might have on 'Finished items' and the OEE. I am proposing that we should only worry about 'Finished } \\
\text { Items', as we certainly do not use low efficiency equipment." [Plant packaging planner] } \\
\text { "With a PDCA session yesterday, we planned two key actions for re-organizing the layout of the can storage area: arranging [storage areas] per brand } \\
\text { and, for each brand, [arranging] the area according to shipping priority. As we went back to addressing the plan earlier this morning, we realized that } \\
\text { 'shipping priority' is all we need. Arranging the storage area 'per brand' only created redundant operations, which we finally discarded." [Warehousing } \\
\text { manager] }\end{array}$ \\
\hline $\begin{array}{l}\text { Local objectives and } \\
\text { indicators are designed }\end{array}$ & $\begin{array}{l}\text { - "For Brewing, we designed a [performance] indicator, "Pouring delay" [departmental indicator], when we understood that the longer the passage from } \\
\text { filtration to carbonation, the lower the control you have on the MEL (...) We observed that some normal delays could happen and we must take them } \\
\text { into account, but I also heard from the microbiology lab that MEL can become irregular with beer brewed over half a day. By piecing together this } \\
\text { information we reckoned that we could afford delays but up to twelve hours, which became our internal target." [Team leader - Brewing] } \\
\text { "“Pasteurizer replenishment' [departmental indicator] was not a new issue to us. However, only thanks to the 'top-five breakdown' nearly all of us } \\
\text { pointed to the need for controlling this operation on a regular basis (...) So we started to get a more precise understanding not only of the quantity to } \\
\text { replenish, but also of how often that must be done. All of this, put together, was formalized into an indicator that we started to use." [Packaging } \\
\text { manager] } \\
\text { "The 'Traceability of pallets' [departmental indicator] is an objective that we wanted in Warehousing in order to control each single shipment that we } \\
\text { make. Its target of 95\% is something that we defined through a sort of lateral thinking process. We asked ourselves: 'What level of satisfaction should } \\
\text { our customers get?'. This fundamental question led us to highlight several elements. An outstanding one was that we should know what exactly are } \\
\text { we sending to customers (...) Together with Accounting, we created an inventory control system that could identify pallets with } 95 \% \text { reliability (...). } \\
\text { We took this as a good level of performance, ensuring that we know almost exactly which pallet, and from which batch, has been sent to whom." } \\
\text { [Controller] }\end{array}$ \\
\hline $\begin{array}{l}\text { Local measurement's } \\
\text { results are compared to } \\
\text { strategic indicators }\end{array}$ & $\begin{array}{l}\text { - "The 'Pre-pouring fermentation checks' [departmental indicator] in my view needs revising; we have set this indicator to the level of three per batch, } \\
\text { but when I see the 'Beer Foam Duration' being off target despite the fermentation checks measured regularly, I start to wonder which piece [of } \\
\text { information] we are missing." [Brewing operator - from original field notes] } \\
\text { "“Dissolved Oxygen' was initially under control through a few [departmental] indicators. Then we had a period of bad results that made us reflect on } \\
\text { the usefulness of one [departmental] indicator that we called 'Re-filler'. I think it is correct that we pay attention to how re-fillers work on the bottling } \\
\text { lines, but poor performance on the 'Dissolved Oxygen' is making us re-think the design of this [departmental] indicator." [Team leader - Packaging] }\end{array}$ \\
\hline
\end{tabular}




\begin{tabular}{|c|c|}
\hline & $\begin{array}{l}\text { - "I was put off when I thought we had found a way to control the 'Delay of lorries' [departmental indicator], but this indicator did not seem to be } \\
\text { helping us with 'Time in Depot' (...) We often got two opposite results." [Logistics specialist - Warehousing] }\end{array}$ \\
\hline $\begin{array}{l}\text { Continuous } \\
\text { improvement sessions } \\
\text { are run again }\end{array}$ & $\begin{array}{l}\text { - "Because the Super KPI of 'Beer Brightness' is signalling that we are at times off-track, we are literally revamping the approach to executing operations. } \\
\text { We are doing, again, continuous improvement exercises in Brewing. This is giving me a different understanding of how I do things, because I see my } \\
\text { actions rather differently." [Plant technical manager] } \\
\text { - "Through various [value stream] mapping sessions we acknowledged that the speed of the [conveyor] belts could be regulated not only per format, but } \\
\text { also per batch size (...) This additional understanding opened up new ways to reach the 'Completed Items' Super KPI." [Line performance supervisor } \\
\text { - Packaging] } \\
\text { "We are trying to re-build our understanding, essentially. (...) I am currently using the ' } 5 \text { Whys' tool in Warehousing to explore additional options to } \\
\text { minimize and control queues at the loading stations, for instance by working with barcodes. This is to try and think of what we could use as additional } \\
\text { [performance] information so as to help ourselves to do better with the 'Time in Depot'." [Plant quality assurance manager] }\end{array}$ \\
\hline Idea boxes are used & $\begin{array}{l}\text { - "I noticed that the temperature in the boiling silo could be held constant for up to } 30 \text { minutes after turning off the boiler (...) I put this observation in } \\
\text { the [idea] box because I thought it was worth considering for the [Super] KPIs we are in charge of." [Brew specialist - Brewing] } \\
\text { "I left a note [in the idea box] when I realized that the 'Completed Items' [Super] KPI could benefit from the additional photocells we were placing on } \\
\text { the packaging lanes... Their correct use and maintenance would be relevant, I thought.” [Plant packaging planner] } \\
\text { "I tried to alternate queues between domestic and export batches ready for shipping in peak loading hours, and I did not see a huge increase in truck } \\
\text { drivers waiting time (...) I wrote a note [to put in the idea box] as I saw potential benefits for the 'Time in Depot'." [Warehousing operator- from } \\
\text { original field notes] }\end{array}$ \\
\hline $\begin{array}{l}\text { Unique names are used } \\
\text { for local indicators }\end{array}$ & $\begin{array}{l}\text { - "The 'Pre-pouring fermentation checks' is not only a [departmental] indicator in Brewing. More than that - it is in fact the usual operation that we have } \\
\text { come to understand to be crucial for a good level of both 'Beer Brightness' and 'Foam Duration'. We talk about fermentation checks everywhere all } \\
\text { the time in this department, so the indicator could not be called otherwise." [Manufacturing development manager] } \\
\text { "We called it 'Replenishment of the vacuum pump' [departmental indicator] so that what we meant could be unmistakeable, especially in our } \\
\text { discussions: precisely what it says." [Head of packaging operations] } \\
\text { - "Because we understood that the delay of trucks could be acceptable up to a certain threshold, we wanted to capture this understanding in a way that } \\
\text { could be not just quantified, but also considered as strategically relevant for our department. To achieve this, we named the departmental indicator } \\
\text { "Delay of trucks", so that its meaning was understood by everybody." [Head of logistics operations] }\end{array}$ \\
\hline Triggers are displayed & $\begin{array}{l}\text { - "The trigger put on the 'Alarm pressure drops' [departmental indicator] works for me as a reminder (...) We devised an operating protocol in the } \\
\text { department on how to handle pressure drops (...) Anytime results are below the trigger, I know I have to intervene and run the protocol. It has become } \\
\text { sort of automatic for me." [Brew manager - Brewing] } \\
\text { - "With triggers we are reminded of the urgent actions we have to take (...) If the 'Filling nozzle outflow' [departmental indicator] goes below [the] } \\
\text { level [of the trigger], that means you have to do two things: clean the nozzle or crank up the pressure." [Packaging specialist] } \\
\text { - "Ever since we started to use the triggers, I feel being kind of constantly told what I have to avoid (...) They are not only numbers - they convey clear } \\
\text { messages." [Plant buyer] }\end{array}$ \\
\hline
\end{tabular}




\begin{tabular}{|c|c|}
\hline Targets are displayed & $\begin{array}{l}\text { - "It is the meaning that targets send out that matters to me when I look at results or take some measurement. That meaning drives me to do the things } \\
\text { we set up to nail the Super KPIs (...) It's not only that you measure with an indicator to see whether you are on target; to me, it's more like: you } \\
\text { measure to understand whether you are doing those things that you previously recognized as helpful to reach the Super KPIs." [Brewing technical } \\
\text { supervisor] } \\
\text { "When we decide on a certain target, what we are saying pretty much to ourselves is: 'let us select those two or three aspects of our [departmental] } \\
\text { activities that we know we have to leverage, in order to achieve our [performance] objectives." [Team leader - Packaging] } \\
\text { "The target put on the 'Time in depot - Export' [departmental indicator] reflects what we learned we needed to achieve an optimal handling of export } \\
\text { shipments (...) It's not only the timing of the loading operations that the indicator forces us to watch, but the target is more like: 'remember what those } \\
\text { few things are that will make you succeed"." [Plant manager] }\end{array}$ \\
\hline $\begin{array}{c}\text { Digital devices to } \\
\text { communicate PM info } \\
\text { are employed }\end{array}$ & $\begin{array}{l}\text { - "By browsing the spreadsheet, I can prepare myself for what we are going to do later on (...) Wherever I see red labels put on measurement results, } \\
\text { for instance, those are triggers. So, I consult the manual that we prepared for triggers, where we have shortlisted problem-solving actions per type of } \\
\text { trigger and I select those actions accordingly (...) I have to say that with this [spreadsheet] system we are hardly wrong and it feels like having the } \\
\text { KPIs always under control." [Plant laboratory technician - Brewing] } \\
\text { "Before we have the pre-shift meeting, I usually look at the screens and I immediately understand how to run it (...) We have a detailed list of things } \\
\text { to follow that I prepare before the meeting starts, and these must be in line with the screens' info. If we are on target with our indicators, then it is } \\
\text { always a matter of encouraging the guys to keep driving the best practices we put in place; if we are off target, instead, I know that we have to do a bit } \\
\text { of problem-solving." [Maintenance supervisor - Packaging] }\end{array}$ \\
\hline $\begin{array}{l}\text { Pen-and-paper artefacts } \\
\text { to communicate PM info } \\
\text { are employed }\end{array}$ & $\begin{array}{l}\text { - "Earlier on, I used to go to my boss to discuss the problems I encountered while doing my job... since we have been using this system of info display } \\
\text { things have changed towards more autonomous actions. (...) I go to check the [physical] notice board and I always look at the 'trigger' board (...) } \\
\text { These boards pretty much instruct me about what I have to do." [Warehousing operator - from original field notes] } \\
\text { "Last week, the trend for the 'Time in depot - national' [departmental indicator] was drawn and posted on the noticeboard. There was a weird drop [in } \\
\text { the trend] that was circled in red... really thick! Circling in read is the way we agreed to signal urgent actions: we were off-trigger for the shipment } \\
\text { prepared in advance (...) When I saw the red circle, I could immediately choose the procedure we needed: I had to either ask for more buffer batches } \\
\text { to [the] packaging [department] or the other option is to re-route batches from 'export' to 'national', if possible." [Manufacturing development } \\
\text { manager] }\end{array}$ \\
\hline
\end{tabular}




\section{Findings}

Our results show that for the employees at the Brewery, aligning operations with the new strategic priorities took place through four distinct cognitive processes - seeking, assembling, adjusting, and finalizing (Figure 2). Moreover, the findings highlight the central role of PM in revising provisional interpretations of the link between strategic priorities and shop floor actions, adapting existing interpretations to new performance information, and retaining interpretations when they afforded stable guidance to the shop floor staff.

We present the findings according to the data structure shown in Figure 2. The structure illustrates the process of generating theoretical constructs (aggregate dimensions) from informant-centric first-order codes and researcher-induced second-order themes.

\subsection{Seeking}

The shift from the old strategy of focusing on product quality to The Manufacturing Principle with its emphasis on efficiency and sustainability produced an upheaval in operations, creating a need for new shop floor behaviours. For employees at the Brewery, the Super KPIs that encapsulated the new strategy signalled the onset of an ambiguous period of change.

We observed how employees experienced conflict between their existing routine operations and the potential operational implications of the new Super KPIs, which they did not yet understand well. Interpreting the routine performance data vis-à-vis the Super KPIs upset the consistency of meaning between old strategic priorities and local actions. This conflict motivated intense discussions driving the search for alternative actions. Discussions took place through pre-shift meetings, continuous improvement meetings, and spontaneous conversations between departmental managers and shop floor staff.

At first, the Brewery attempted to use the Super KPIs as technical metrics to drive operations directly. Senior managers showed the formulas and provided instructions for calculating the department's performance in ways consistent with Super KPI targets. They asked the team leaders to take hourly measurements and to present the results during the following day's pre-shift meeting. In these meetings, the teams presented performance data visually in the form of a line graph. To produce the graph, team leaders averaged performance 
results across multiple production cycles (e.g., batch completion) and plotted the average against the Super KPI target. The peaks and troughs on these graphs were colour-coded, thus encouraging everyone to focus on important cues. Subsequently, the manager asked the workers to explain - in other words, attach meaning to - the gaps between targets and results. The workers' explanations often complemented the data on the graph: "I made diagrams for our production cycles against each Super KPI assigned to the department. On the basis of these diagrams, we started to see how [the performance of] the lines varied for each KPI... Peaks and troughs corresponded to the specific hours in a shift. I asked them, 'What happened in those moments?' ... For that KPI, bad news like 'pipes got clogged during the [preventive] maintenance procedures' was reported. Alternatively, they spent some time telling me how well they performed the procedure, like: 'We could synchronize the closing of valves pretty well to avoid pressure alarms." [Team Leader, Brewing].

These discussions provided a vehicle for bracketing global performance data, in other words, looking for connections between the overall performance results and the specific shopfloor events that had generated these results.

Despite engaging in these discussions, people at the Brewery noticed that simply evaluating the output of production processes against a small number of Super KPIs left various issues unexplained. For example, describing the Super KPI of Beer Brightness, the Brew Manager said: "We keep having a low Beer Brightness result. It could be due to any or all of the maintenance problems we have had: badly maintained filters that get broken, dirty vats in fermentation or boiling... If we do not see how these problems happen, check on whether standard operating procedures have been followed in the right way, and ascertain to what extent each of these problems impacts our target, we'll never get out of this nagging trouble. We have one measure - Beer Brightness - which does not tell you what makes 'the brightness brighter'!".

For employees at the Brewery, this limited understanding elicited the search for cues that would complement those bracketed through evaluating performance data. The staff extracted these cues directly from the shop floor activities. They did this by observing the manufacturing processes directly. These observations enabled the recognition of relevant process features (including people's behaviours) that the staff perceived as important for understanding the connections between shop floor actions and the Super KPIs. These features provided additional information for performance-related discussions. 
For example, Packaging was struggling with implementing "one-piece-flow" procedures required for improving performance on the Completed Items Super KPI. Simply looking at the graphs did not allow the managers to understand where the issue was. Therefore, they decided to observe how "one-piece-flow" was carried out: "We realized that Line 1 and Line 2 had been consistently performing differently. ... Some guys told me that their biggest difficulty was with sticking labels on different SKUs, but we were not sure whether this was really the case. ... I felt I needed to go to the lines, looking at how bottles lined up on the conveyor belt. ... I started to think in terms of different SKUs, for example, "How long do the labelling operations take for the 0.33 [ml] format on Line 1? And for the $0.66[\mathrm{ml}]$ one on Line 2?" and try to figure out [what] one-piece-flow [meant] for each packaging line" [Packaging Manager].

Through bracketing global performance data and recognizing relevant process features, people sought out the aspects of performance that they perceived as relevant for restoring the cognitive consistency disrupted by the new strategy. Seeking, therefore, embodied a collection of experiences through which people in the Brewery began to interpret the connection between the Super KPIs and the shop floor operations.

\subsection{Assembling}

As the staff analyzed performance data and observed the production process, they produced multiple interpretations of what the new strategic priorities might mean for daily work on the shop floor. As discussions continued, however, they were gradually narrowing down the variety of possible interpretations of issues to a smaller set of plausible ones. The Brewery's departments needed to select the relevant local performance information to connect multiple interpretations and reach consensus that would enable them to devise action plans.

Using process mapping and continuous improvement tools, the employees at the Brewery captured local performance information. A good illustration of this process was the way the staff used Plan-Do-Check-Act (PDCA) wheels and fishbone diagrams.

The staff used fishbone diagrams to explore the potential causes of a critical aspect of performing a task. They would first draw a long horizontal line indicating the issue that was being examined and then attached a number of 'prongs' - slanted lines - representing potential causes. During the discussion, managers and shop floor staff suggested various items which would be examined, added, or eliminated. This process resulted in new prongs appearing on 
the diagram and others being erased. The analysis of labelling machine breakdowns in Packaging provides a good example of this process. The staff was investigating an issue with the setup of these machines for packaging bottles of different sizes, which was acknowledged as critical for the Super KPI of Equipment Efficiency: "We began the analysis by [production] line by machine lost time to understand where the problem was lurking. ... Several prongs were drawn on the [fishbone] diagram by the persons who had something to say. ... A [machine] operator told me: 'Look at the speed of Machine A. I don't think this is good for this format because I usually have scraps of labels when the operation runs too fast. If I lower the speed, it happens less.' We started to reflect together, and we deemed 'high speed' a relevant cause. ... We did not have a prong for 'speed' on the diagram yet ... and we added it on. ... We also erased the 'machine lost time' [prong] proposed before, as we noticed it was too general. ... Looking at the whole picture we got, we concluded that setting up the labeller would require attention to different speeds" [Maintenance Supervisor - Packaging]. Adding and removing content thus enabled the collective selection of cues and produced a collective meaning that people deemed plausible.

These discussions also highlighted the need for new local performance objectives and indicators that were necessary to maintain a meaningful connection between strategic indicators and operational activities. Setting these objectives and developing new indicators enabled the employees to prioritize specific areas of operations that needed to change to accommodate the new strategic priorities.

For example, the Brew Manager working on the missed Beer Brightness Super KPI target recounted the following episode: "I started [by asking]: 'What contribution do you make to the achievement of the Beer Brightness target? Tell me how you run your activities.... One guy from the filtration line replied: 'In filtration, I have been changing strainers every three hours' ... Another guy [from the fermentation line] said that the MEL [an organic component of beer wort causing beer clarity] was remarkably unstable while wort was poured out and sent to filtration. ... While drawing the deployment chart, I figured out that changing strainers so often in an attempt to improve beer brightness would thus depend on pouring wort. ... I understood that stabilizing the MEL was an important and critical objective to be pursued."

The identification of objectives highlighted in this example resulted in the formulation and refinement of two new indicators: "MEL stabilization" and "Labeller setup". Similar processes took place across the entire plant. As a Team Leader from Brewing noted, "With these [departmental] measures we want to pay attention to the main points we presented in the 
sessions, such as 'How long does it take for a tank to be decanted?' [Indicator 1]. 'What is the transfer period between fermentation and storage?' [Indicator 2].”

As this work progressed, each department developed a "Table of Departmental Indicators" - a template of local performance indicators that captured what people perceived as operational priorities and connected them to the Super KPIs in a meaningful way. An example from Brewing is presented in Table 4. Initially, this table contained a small number of initial indicators. However, as the work on aligning operations with strategy continued, and as we discuss in a later section, the staff kept adding new indicators.

Taken together, the selection of local performance information and the prioritization of issues allowed people at the Brewery to begin assembling the understanding of how actions on the shop floor connected with the new strategic priorities. As the evidence reported in this section shows, reaching this understanding encompassed cognitive heuristics whose outcome was malleable and therefore open to on-going re-arrangement. 
Table 4. Table of departmental indicators - Example from Brewing

\begin{tabular}{|c|c|c|c|c|c|c|c|}
\hline Super KPIs & $\begin{array}{c}\text { Dissolved } \\
\text { oxygen in beer }\end{array}$ & $\begin{array}{l}\text { Beer foam } \\
\text { duration }\end{array}$ & Beer Brightness & $\begin{array}{c}\text { Water } \\
\text { consumption }\end{array}$ & $\begin{array}{c}\text { Electricity } \\
\text { consumption }\end{array}$ & $\begin{array}{l}\text { Equipment } \\
\text { efficiency }\end{array}$ & $\begin{array}{l}\text { Safety of } \\
\text { operations }\end{array}$ \\
\hline \multirow[t]{2}{*}{$\begin{array}{l}\text { Initial } \\
\text { Indicators }\end{array}$} & $\begin{array}{l}\text { 'Density check } \\
\text { before } \\
\text { injection' }^{[1]}\end{array}$ & $\begin{array}{c}\text { 'Microparticles } \\
\text { sediment } \\
\text { removal' }\end{array}$ & $\begin{array}{c}\text { 'MEL } \\
\text { stabilization' }\end{array}$ & 'Cleansing vats' & 'Sudden spikes' & $\begin{array}{l}\text { 'Steam } \\
\text { pressure } \\
\text { check' }\end{array}$ & $\begin{array}{l}\text { 'Near miss per } \\
\text { department' }\end{array}$ \\
\hline & & 'Pouring delay' & $\begin{array}{l}\text { 'Changed } \\
\text { strainers' }\end{array}$ & $\begin{array}{c}\text { 'Refilling } \\
\text { pasteurizer' }\end{array}$ & $\begin{array}{c}\text { 'Restart } \\
\text { refrigeration } \\
\text { system' }\end{array}$ & $\begin{array}{c}\text { 'Silo } \\
\text { replenishmen } \\
\text { t check' }\end{array}$ & \\
\hline \multirow[t]{3}{*}{$\begin{array}{l}\text { Added } \\
\text { Indicators }\end{array}$} & $\begin{array}{c}{ }^{\prime} \mathrm{O}_{2} \text { overflow } \\
\text { peaks' }\end{array}$ & $\begin{array}{l}\text { 'Yeast level } \\
\text { after pouring' }\end{array}$ & $\begin{array}{c}\text { 'MEL } \\
\text { stabilization in } \\
\text { fermentation' }\end{array}$ & 'Overflow silo 1' & $\begin{array}{c}\text { 'Boiler } \\
\text { overwork' }\end{array}$ & $\begin{array}{c}\text { 'Change of } \\
\text { high-pressure } \\
\text { valves' }\end{array}$ & $\begin{array}{l}\text { 'Near miss: } \\
\text { Other } \\
\text { unpredicted } \\
\text { events' }\end{array}$ \\
\hline & $\begin{array}{c}\text { 'CO } \mathrm{CO}_{2} \text { purity level } \\
\text { per tank }{ }^{\text {[3] }}\end{array}$ & $\begin{array}{l}\text { 'Pre-pouring } \\
\text { fermentation } \\
\text { checks' }\end{array}$ & $\begin{array}{c}\text { 'MEL } \\
\text { stabilization in } \\
\text { boiler' }\end{array}$ & 'Overflow silo 2' & $\begin{array}{c}\text { 'Switching } \\
\text { cooling tower } \\
\text { usage' }\end{array}$ & $\begin{array}{c}\text { 'Leakage at } \\
\text { pouring } \\
\text { stations' }\end{array}$ & $\begin{array}{l}\text { 'Near miss: } \\
\text { steam burst } \\
\text { boiler' }\end{array}$ \\
\hline & & $\begin{array}{l}\text { 'Steam } \\
\text { temperature in } \\
\text { boiler' }\end{array}$ & $\begin{array}{c}\text { 'MEL } \\
\text { stabilization in } \\
\text { silos' }\end{array}$ & $\begin{array}{l}\text { 'Pressure peaks } \\
\text { cooling tower' }\end{array}$ & $\begin{array}{l}\text { 'Boiler pre- } \\
\text { warming' }\end{array}$ & $\begin{array}{l}\text { 'Alarm } \\
\text { pressure } \\
\text { drops' }\end{array}$ & \\
\hline
\end{tabular}

Example of indicators' formulae:

${ }^{[1]}$ No. of checks signalling non-constant (i.e., irregular) density levels;

${ }^{[2]}$ Value of oxygen density peaks for each beer tank (measured as parts per billion);

${ }^{[3]}$ Average carbon dioxide levels in beer, before and after pouring operations (measured as parts per billion). 


\subsection{Adjusting}

The employees brought performance data generated by the newly designed local indicators to the discussions about the performance of the plant against Super KPIs' targets. However, initially, and contrary to the employees' expectations, the new indicators made the task of connecting Super KPIs with operations more, not less, difficult. Local performance data generated confusion and questions, sending people in the Brewery back to the process of identifying salient information (seeking), attempting to interpret it, and then modifying local performance indicators (assembling). The ongoing local measurements in each department provided opportunities for adjusting the initial understanding of the processes that had generated the original set of local performance objectives and indicators. This process of adjusting the initial understanding took place through iterations between seeking and assembling.

As shop floor work continued to respond to the pressure imposed by the Super KPIs, local performance indicators furnished new data that triggered additional sensemaking. By interrogating local indicators' results, the employees went through a process of testing the understanding they had previously gained through these indicators. The Super KPI of 'Time in Depot' used in the Warehousing department provides a good example. Time in Depot referred to the total time the product spent in storage, from leaving the packaging line to being taken outside the premises. Initially, the Warehousing team broke this Super KPI down into several local indicators that were included in the Table of Departmental Indicators. One of these local indicators was 'Time in Depot - Export', which focused on export shipments only. However, when the staff compared the data from this indicator to the target specified by the Super KPI, they realised that while the local indicator was on target, the Super KPI target was missed. This discrepancy required the manager to examine the data for salient cues: "We keep reducing our Time in Depot - Export, as the measure says. But if we strive to wrap pallets for export and place them on the platforms quickly and our Super KPI still keeps being red, then there is something that we are missing in our departmental indicator. ... Some suggested that this may be about truck loading, but I also wonder whether the handling activities might support the loading better" [Warehousing Manager].

The employees then had to revise their understanding, which involved gathering more cues, re-interpreting their initial views, and consequently adjusting the initial meanings given to the local indicators. 
A tool used by the Brewery to help the employees accomplish such tasks were idea boxes - receptacles placed in all three departments for collecting operators' suggestions and observations. Their purpose was to "catch what people really perceived as critical and important to pay attention to in their job" (Plant Technical Manager). The notes placed in the box included statements such as "the number of pallets returned affects loading time". Building on the episode with Time in Depot, the Logistics Specialist in Warehousing reported: "Several snippets from the box were presented: 'the number of pallets returned affects loading time', 'queues increase when pallets are placed outside the printed lanes', 'pallets lined up on the loading platforms in advance speed up loading', etc. ... Mario [operator] started to say: 'What if we consider the first point? How does the chart change?' ... For the 'pallets lined up in advance' suggestion, I argued that it would improve the Time in Depot [Super KPI] for both Export and National [the departmental indicators], because you could save lead time and use it to work on bottlenecks somewhere else, thus lowering the Time in Depot as we are asked to do. ... My suggestion, among others, was well received and helped to define a new [departmental] indicator: 'pallets loaded in advance.' The boxes thus generated new cues that allowed the employees to revise their understanding of how local actions aligned with strategic objectives. More indicators could be added at this stage (see Table 4 for the full Table of Departmental Indicators in Brewing).

Overall, employees at the Brewery were able to adjust their initial understanding of the connection between Super KPIs and the required changes in operational activities by going through several cycles of testing it against the data produced by the local indicators and revising it as necessary. PM was thus central to the process of adapting operations to the new strategic priorities.

\subsection{Finalizing}

Adjusting produced three Tables of Departmental Indicators - one for each department. The tables contained local indicators that highlighted the most important actions required for reaching Super KPIs' targets. These local indicators represented the retained understandings of Super KPIs that were locally meaningful and actionable. These understandings were then finalized - i.e., embedded into the language and artifacts used by the employees. This embedding constrained variation in local actions, thus ensuring the enduring consistency of operations with the Super KPIs. PM again played a central role in supporting this process. 
Developing a local PM language was one of the means of supporting the finalizing phase. A language emerged within each department, used by the employees for communicating with each other, especially with respect to technical PM matters. These local languages employed vocabulary of unique names attached to local objectives and indicators. The names often came directly from the idea boxes, deployment charts, or problem-solving tools.

For example, the Head of Packaging Operations described the development of one local indicator: "The '[Alarm] - Sudden decrease of caps' [indicator] was fished out of the [idea] boxes. We considered using it more than a few times to help explain why the [Super KPI of] Finished Items had decreased, because we have seen that the corking machine can get jammed if not enough caps are in the loader, and bottles consequently get broken. ... Now, '[Alarm] Sudden decrease of caps' is also a taken-for-granted aspect of our discussions in meetings."

The local language in each department was supported by trigger and target values introduced by the departmental managers to ensure that the new indicators informed appropriate action. Triggers represented the minimum (maximum) level of performance, below (above) which managers would initiate remedial actions. Targets specified the level of performance considered "optimal” for achieving the department's Super KPI objective. The setting of trigger and target values "arose from talking in continuous improvement sessions about how best to make the results of lower [departmental] measures meaningful" [Plant Manager] and made heavy use of the local language. For example, in Packaging, the following episode captured the use of triggers: "We discussed the [Super KPI of] Equipment Efficiency that was causing a lot of maintenance issues. ... The change of monoblocs to fill kegs [a departmental performance indicator] ... was often done with spare parts purchased from different suppliers [and] at different prices, which could be costly. ... We identified the absolute minimum of things you had to avoid to prevent costs from surging, which we translated into the trigger. It has a clear message: 'Do not go beyond XXX Euros'.... We know that as long as the purchase of spare parts is done accordingly, so costs do not exceed the trigger, maintenance staff can handle procurement as they see fit. But still, they must not go beyond the threshold we set up" [Controller].

The example above demonstrates that, besides supporting the development of local language, triggers and targets began to bring normative meaning into routine activities. In other words, they acted as normative devices that implied a specific direction for various actions. 
The prescriptive meaning that triggers and targets brought to the shop floor operations was reinforced by artefacts - technical measurement devices that the staff developed to support the Table of Departmental Indicators. In the Packaging hall, video screens were hung on the ceiling to display real time performance, with alarms and flashing red lights indicating when triggers were exceeded; Brewing developed Excel spreadsheets, where results exceeding the trigger values were highlighted in red; and in Warehousing, hard copies of spreadsheets were displayed on notice boards, with trigger values reported separately. Commenting on the effect of these artefacts, the Plant Manager said: "People automatically meet when the alarm rings. ... By having measures so detailed ... it is enough to look at the results to see whether problem solving needs to be initiated or not. ... Each result is now also associated with a specific intervention of the manager in charge of controlling this or that specific objective."

Thus, the development of the local language and the embedding of normative meaning into the activities in each department enabled the employees throughout the plant to finalize their understanding of how the relevant strategic objectives contained in the Super KPIs could be achieved. The language, triggers, targets, and artefacts reflected a set of retained and increasingly normative interpretations of the ways in which local actions related to the plant's strategic objectives.

Overall, the case shows how PM activities can provide the cognitive support that enables the adaption of local action to new strategic priorities. More specifically, the strategic direction communicated to the Brewery through a set of Super KPIs materialized into local performance objectives and indicators by means of a complex and iterative process of creating, re-defining, and embedding actionable local meanings. These meanings, in turn, ensured that operations changed to gain alignment with the organization's new strategy.

\section{Discussion}

\subsection{Theoretical contributions}

This study set out to address an important theoretical shortcoming in the literature on alignment. This shortcoming is the result of a tendency to emphasize the behavioural aspects of alignment, whilst overlooking the cognitive aspects. By employing sensemaking as a lens for investigating the process of aligning operations with a new strategy, we contribute to fill this theoretical gap. Our findings suggest that consistent organizational action requires a corresponding consistency of meanings. The emergence of this consistency of meanings, 
however, is a complex and iterative process of cognitive adjustments enabled by PM and comprising four phases. The emergent theoretical model of this process is illustrated by Figure 3 below.

The process illustrated in the model is initiated when existing alignment is disrupted, for example when an organization introduces new strategic priorities. In such cases, the information generated by the existing local indicators may lose its usefulness, because these indicators still support actions related to the old strategy. The resulting cognitive mismatch then functions as the source of disruption. In the first phase of the process, both managers and shop floor staff seek out cues related to operational performance which are considered relevant for bringing operations in line with the new strategic priorities. These cues may be provided both by the existing local performance indicators and by the direct observation of operational processes. Performance measurement thus provides the necessary input into the process of seeking relevant new information.

The second phase of alignment involves generating provisional new meanings, as the aforementioned cues are assembled into a collectively agreed understanding of the link between operations and strategy. New local indicators may also be introduced in this phase to provide the missing information, improving and supporting the quality of the interpretive process taking place. However, this work may not generate the desired consistency of meaning immediately; instead, a satisfactory understanding of the link between shop floor actions and the new strategic priorities may involve trial and error. In this case, provisional meanings require further adjustment through reinterpreting and reassembling performance-related cues and amending the local performance indicators. The refinement of meaning necessary to support the alignment of strategy and operations may thus require multiple cycles of adjustment.

The process enters the final phase when the understanding of the link between strategy and shop floor actions becomes sufficient for taking actions that are consistent with the new strategic priorities. In this phase, locally meaningful operational procedures and artefacts are introduced to support the interpretive function of local performance indicators. These artefacts serve as a cognitive aid to remind the frontline staff what actions are required and thereby stabilize the emerging alignment. 
Figure 3. Cognitive processes of internal alignment

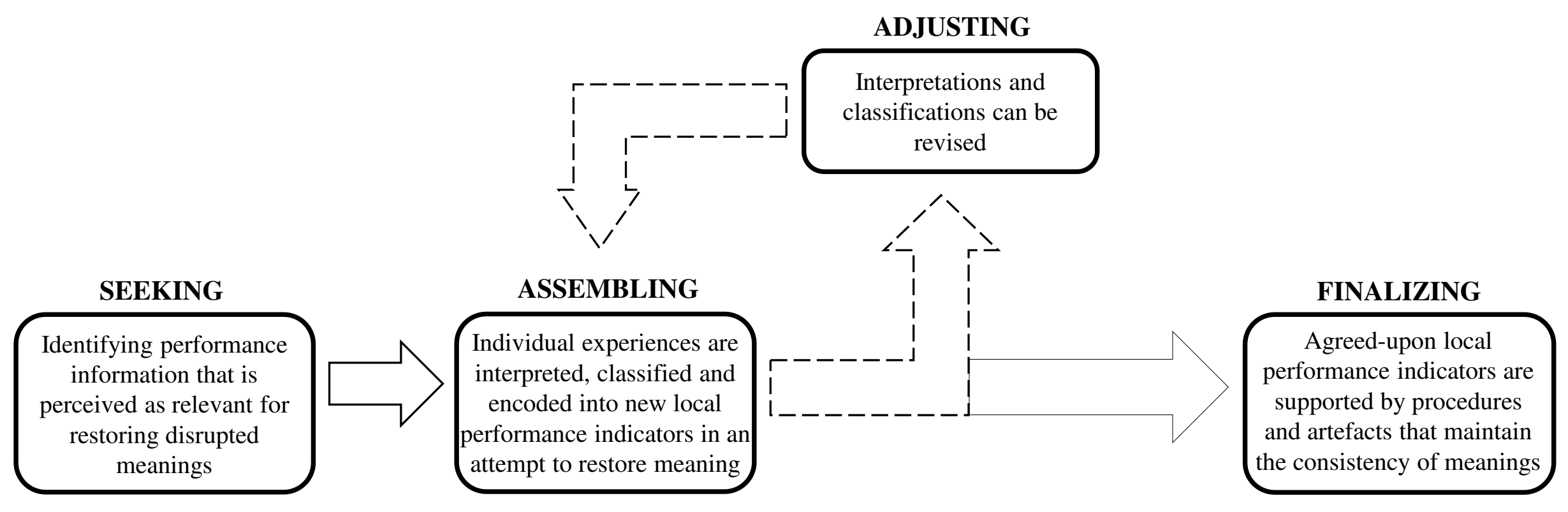


Overall, the model explains the role of PM in supporting cognitive processes that underpins the adaptation of local actions with strategic objectives in pursuit of organizational goals. Thus, it presents a fuller theoretical conception of alignment that is more in line with comprehensive performance management and management control systems frameworks (e.g., Ferreira and Otley, 2009; Broadbent and Laughlin, 2009). This view of alignment has a number of implications for the current understanding of the use of PM in aligning operations with strategy.

First, our findings suggest a way of integrating various studies of the emergence of effective local PM into a more general account of internal alignment. Earlier work pointed out the need to explain employee engagement with lower-level PM in situations when higher-level, strategic indicators do not afford sufficient guidance for shop-floor actions (e.g., Wouters and Wilderom, 2008; Jordan and Messner, 2012; Groen et al., 2012). These studies invoked the concept of "experience-based PM systems development process" centred on the role of employees" "intimate familiarity with the operational processes" (Wouters and Wilderom, 2008, p.509) or similar notions (Reinking et al., 2020; Nudurupati et al., 2021). These works highlighted the involvement of lower organizational levels in the design of PM systems as crucial for achieving internal alignment. However, these studies are mostly design-centred they take for granted how local knowledge is mobilized in the day-to-day pursuit of the organization's strategic objectives.

The model developed in our study, instead, helps explain the integration of high-level objectives on the one hand, and local perceptions and knowledge on the other. It suggests that iterative cycles of interpreting local performance reduce the initial uncertainties introduced by strategic performance indicators. It theorizes how people interrogate, interpret and classify shop-floor events to produce and assemble cues so as to create a shared and agreed-upon understanding of the link between strategy and operations. This study's view of alignment suggests that the development of effective local performance indicators is dependent on this interpretive work and requires a substantial cognitive effort. The process of arriving at the "MEL stabilization" and "Labeller setup" indicators provides a good illustration of such effort. These two departmental indicators originated from multiple assemblages of local cues, initially producing provisional local indicators that the staff subsequently refined in various discussions to clarify and operationalize the Super KPIs of "Beer Brightness" and "Equipment Efficiency".

In addition, our model explains how cognitive processes at multiple organizational levels are connected. The study suggests that the interpretation of strategic objectives is not 
exclusively the prerogative of managers (e.g., Hall, 2010); instead, employees throughout the organization draw on PM to engage in the process of sensemaking, generating a variety of meanings of strategic objectives and harmonizing them through collective discussions. Accordingly, we, first, extend Bititci et al.'s (2011) emphasis on managerial perceptions and show how, in the process of aligning operations with strategy, managerial perceptions can come together with those of frontline staff in the process of assembling and revising the understanding of the link between strategic priorities and local actions. As such, the model also provides a tentative explanation for the concept of boundary spanning-based learning at the heart of alignment hypothesized by McAdam et al. (2017). Our study suggests that the use of PM for aligning operations with strategy provides a means to facilitate the continuous adjustment and integration of individual cognitions throughout the organization. The ability to foster this integration is an important organizational capability that is especially relevant for supporting strategy implementation.

Second, in contrast to the literature which claims that the effectiveness of PM systems in achieving internal alignment depends on features and characteristics that are built into the system (Bourne, 2002; Kaplan and Norton, 2006; Hanson et al., 2011; Micheli and Mura, 2017; Abernethy et al., 2021), our study suggests a dynamic and recursive perspective on alignment. The case study reveals how managers and shop floor staff continuously sought to resolve mismatches between their initial interpretation of the meaning of strategic indicators and the performance results they observed. Consequently, they generated an actionable understanding of the Super KPIs and their links to shop floor processes over multiple iterations of sensemaking processes. As these mismatches occurred and results were discussed among the staff, people adjusted their understandings and revised the content of departmental performance indicators. For example, "Time in Depot - Export" had to be amended several times during its use in the Warehousing department. It was through such adjusting loops that operational processes were finalized, in line with the strategic priorities expressed by the Super KPIs.

Thus, our study builds on the existing critique on the alignment of operations through centrally developed PM systems (e.g., Johnston and Pongatichat, 2008; Kolehmainen, 2010; Pellinen et al., 2016) and suggests that upfront specification of causal connections between strategy and local indicators may fail to account for the complexities involved in establishing alignment (see Bourne et al., 2018). Instead, our study suggests that aligning operations with strategy and designing appropriate local indicators is carried out by continuously reflexive agents. Employees' reflexivity as sense makers mobilizes situated understandings that can 
render a PM system increasingly functional, provided that time is allowed for the adjustment loops to take place.

Third, as a consequence of our conceptualization of alignment as a dynamic and recursive sensemaking process, the presumed stability of alignment as a state (Khalili Shavarini et al., 2013; Lucianetti et al., 2019) needs re-visiting. For example, the final versions of the "Tables of departmental indicators" in each department reflected a temporarily stable state, where understandings were "finalized" and shop-floor processes were aligned with the strategic priorities. However, the tables would be revisited if managers or shop floor staff lost their understanding of the link between the table and the Super KPIs. Our model thus suggests that a state of alignment between operations and strategy is never complete and is only temporarily stable, i.e, alignment is a continuous and dynamic process that requires constant maintenance. Recent work has explored the conceptual foundation of this view (Merchant and Otley, 2020), and our study provides an empirical explanation of the structure and dynamics of this process.

Finally, our study offers a potentially fruitful avenue for advancing the emerging conversation on the unintended consequences of PM. Studies in this area (e.g., Gray et al., 2014; Franco-Santos and Otley, 2018) suggested that one of the drivers of unintended consequences might be the excessive emphasis on the behavioural aspect of alignment - i.e., the assumption that careful a priori design of performance indicators is alone sufficient for generating desired behaviours. Our study lends additional support to this insight by highlighting the importance of the cognitive aspect of alignment and suggesting that generating consistent behaviours indeed requires a corresponding consistency of meanings. This implication, however, should be interpreted with caution, as we did not explicitly study the consequences of PM and, therefore, more research is needed to examine how the model of alignment presented here contributes to explaining the phenomenon of unintended consequences.

\subsection{Managerial implications}

The study has a number of practical implications. First, the findings emphasize that internal alignment cannot be established only by specifying strategic priorities and the associated high-level performance indicators. Instead, the organization must live through the complex and resource-intensive process of translating strategic priorities into meaningful operational changes with the help of PM. Therefore, organizations may seek to complement 
traditional approaches to driving internal alignment with providing space for sensemaking occasions, where high-level performance indicators could be contextualized and connected to shop floor realities. In this sense, the ability to take a reflexive stance may be as important as the technical PM knowhow.

Second, the model in this study may help formulate diagnostic questions for assessing the cognitive readiness of the organization to establish alignment. For example, do shop floor staff have working conditions that enable them to develop an understanding of strategic indicators? Are local indicators sufficiently meaningful to support a strategy or is additional sensemaking work required? Developing answers to these questions will enable managers to support the cognitive processes involved in generating and maintaining a consistent understanding of the link between strategy and operations.

Finally, the empirical setting of the study provides an indication of cognition-friendly practices that could increase the effectiveness of using PM for aligning strategy and operations. Such practices may include purposeful observations of production processes, experimentation, practices for collective decision making, visual thinking, and the use of visual aids.

\section{Conclusions}

This study has explored the cognitive processes involved in aligning shop floor operations with new strategic priorities through PM. It has theorized internal alignment as a cognition-centred phenomenon and proposed a view of internal alignment as an ongoing interpretive process, which is sustained by PM and brings about the consistency of meanings required for achieving strategy-consistent behaviors. As such, this paper responds to calls for a more complete theoretical treatment of alignment and complements earlier research that has mainly focused on the behavioral aspect of the phenomenon.

The findings in this paper need to be considered in light of the limitations associated with our research methods and theoretical lens. Consistent with the methodological fit criterion (Edmondson and McManus, 2007), our in-depth single case study is particularly appropriate for building theory about cognitive processes of alignment. However, to extend these theoretical insights beyond the instructive idiosyncrasies of our single case study, we suggest employing additional methods to advance this knowledge to more mature levels.

First, multiple case studies may refine our theorization by grounding it in a broader empirical context (McAdam et al., 2017). For instance, future research efforts may further 
develop our model through investigating multiple sites within a large organization. Such extension would help promote an understanding of interactions between HQ and operating units/subsidiaries and their substantive effects on cognitive processes of internal alignment.

Second, hypothesis-driven, quantitative studies would help test such refinements and make the insights generalizable across multiple empirical settings. In this vein, future research may develop operational measures for the cognitive aspects of alignment, perhaps aided by Hanson et al.'s (2011) work on defining survey-based measures of strategic alignment. Such an approach would also further validate the relationships between the individual elements of our model.

Furthermore, our case material is limited to manufacturing operations. Hence, there is scope for further inquiry into the nature of cognitive processes of alignment in service operations to provide transferability of our findings to different contexts. In addition, we suggest that future work may continue our line of inquiry by examining the role of alternative cognition-centred lenses, for example investigating how designing and implementing performance indicators as a top-down process can help or hinder people's reflexivity and cognitive processing when compared to more horizontal approaches or exploring the role of individual cognitive styles in organizing and processing performance information for establishing internal alignment (cf. Aggarwal and Woolley, 2018). Another useful direction for further research might be to connect the work on the cognitive aspect of alignment with other factors that contribute to performance outcomes - for example, the use of incentives and compensation.

Finally, the sensemaking perspective enables researchers to ask broader questions that explore alternatives to rational and design-oriented approaches to PM-driven strategy deployment. Questions about how organizations continue to function when internal alignment breaks down and how cognitive processes contribute to the ongoing effectiveness of imperfect performance information can be usefully investigated by adopting sensemaking as a theoretical lens.

\section{Notes}

[1] Sample interview questions may be obtained from the corresponding author.

\section{References}


Abernethy, M.A., Dekker, H. C. and Grafton, J. (2021), "The influence of performance measurement on the processual dynamics of strategic change", Management Science, Vol. 71, No. 1, pp. 640-659.

Aggarwal, I. and Woolley, A.W. (2018), "Team creativity, cognition, and cognitive style diversity", Management Science, Vol. 65, No. 4, pp. 1586-1599.

Beer, H. and Micheli, P. (2017), "How performance measurement influences stakeholders in not-for-profit organizations", International Journal of Operations \& Production Management, Vol. 37, No. 9, pp.1164-1184.

Bititci, U., Ackermann, F., Ates, A., Davies, J., Garengo, P., Gibb, S., MacBryde, J., Mackay, D., Maguire, C., van der Meer, R., Shafti, F., Bourne, M. and Umit Firat, S. (2011), "Managerial processes: business process that sustain performance", International Journal of Operations \& Production Management, Vol. 31, No. 8, pp. 851-891.

Bititci, U., Bourne, M., Cross (Farris), J. A., Nudurupati, S. S., and Sang, K. (2018), “Towards a theoretical foundation for performance measurement and management", International Journal of Management Reviews, Vol. 20, No. 3, pp. 653-660.

Broadbent, J. and Laughlin, R. (2009), "Performance management systems: A conceptual model", Management Accounting Research, Vol.20, No.4, pp. 283-295.

Bourne, M. (2002), "The success and failure of performance measurement initiatives", International Journal of Operations \& Production Management, Vol. 22, No. 11, pp. 1288.

Bourne, M., Franco-Santos, M., Micheli, P. and Pavlov, A. (2018), "Performance measurement and management: a system of systems perspective", International Journal of Production Research, Vol. 56, No. 8, pp. 2788-2799.

Chenhall, R., and Euske, K. J. (2007), "The role of management control systems in planned organizational change: An analysis of two organizations", Accounting, Organizations \& Society, Vol. 32, pp. 601-637.

Chenhall, R., Hall, M. and Smith, D. (2013), "Performance measurement, modes of evaluation and the development of compromising accounts", Accounting, Organizations \& Society, Vol.38, pp.268-287.

Corley, K. G. and Gioia, D.A. (2004) "Identity Ambiguity and Change in the Wake of a Corporate Spin-Off”, Administrative Science Quarterly, 49(2), pp. 173-208.

Dahler-Larsen, P. (2014), "Constitutive effects of performance indicators", Public Management Review, Vol. 16, No. 7, pp. 969-986.

de Menezes, L. M., and Escrig, A. B. (2019), "Managing performance in quality management: A two-level study of employee perceptions and workplace performance", International Journal of Operations \& Production Management, Vol. 39, No. 11, pp. 1226-1259.

Edmondson, A. C. and McManus, S. E. (2007), "Methodological fit in management field research", Academy of Management Review, Vol.32, N.4, pp. 1155-1179.

Eisenhardt, K. M. and Graebner, M. E. (2007), "Theory building from cases: Opportunities and challenges", Academy of Management Journal, Vol.50, N.1, pp.25-32.

Ferreira, A. and Otley, D. (2009), "The design and use of performance management systems: An extended framework for analysis", Management Accounting Research, Vol.20, No.4, pp. 263-282. 
Franco-Santos, M. and Otley, D. (2018), "Reviewing and theorizing the unintended consequences of performance management systems", International Journal of Management Reviews, Vol. 20, No. 3, pp. 696-730.

Gioia, D.A., Corley, K.G., Hamilton, A.L. (2012), "Seeking qualitative rigor in inductive research: Notes on the Gioia Methodology", Organizational Research Methods, Vol. 16, No. 1, pp. 15-31.

Gray, D., Micheli, P. and Pavlov, A. (2014), Measurement Madness: Recognizing and Avoiding the Pitfalls of Performance Measurement, Wiley.

Groen, B., Wouters, M., Wilderom, C. (2012), "Why do employees take more initiatives to improve their performance after co-developing performance measures? A field study", Management Accounting Research, Vol. 23, pp. 120-141.

Hall, M. (2010), "Do comprehensive performance measurement systems help or hinder managers' mental model development?", Management Accounting Research, Vol.22, pp.68-83.

Hanson, J., Melnyk, S. and Calantone, R. (2011), "Defining and measuring alignment in performance management", International Journal of Operations \& Production Management, Vol. 31, No. 10, pp. 1089-1114.

Johnston, R. and Pongatichat, P. (2008), "Managing the tension between performance measurement and strategy: coping strategies", International Journal of Operations \& Production Management, Vol. 28, No. 10, pp. 941-967.

Jordan, S. and Messner, M. (2012), "Enabling control and the problem of incomplete performance indicators", Accounting, Organizations \& Society, Vol. 37, pp.544-564.

Kaplan, R.S. and Norton, D.P. (2006), Alignment: Using the Balanced Scorecard to Create Corporate Synergies, Harvard Business Press, MA.

Ketokivi, M. and Choi, T. (2014), "Renaissance of case research as a scientific method", Journal of Operations Management, Vol. 32, No. 5, pp. 232-240.

Khalili-Shavarini, S., Salimian, H., Nazemi, J. and Alborzi, M. (2013), "Operations strategy and business strategy alignment model (case of Iranian industries)", International Journal of Operations \& Production Management, Vol. 33, No. 9, pp. 1108-1130.

Kolehmainen, K., (2010), "Dynamic strategic performance measurement systems: Balancing empowerment and alignment", Long Range Planning, Vol.43, No.4, pp. 527-554.

Langley, A. and Abdallah, C. (2011), Templates and turns in qualitative studies of strategy and management. In: Ketchen, D.J. and Bergh, D.D. (eds.) Building Methodological Bridges. Research Methodology in Strategy and Management 6. Bingley, UK: Emerald Group Publishing, pp. 201-235.

Lucianetti, L., Battista, V., and Koufteros, X., (2019), "Comprehensive performance measurement systems design and organizational effectiveness", International Journal of Operations \& Production Management, Vol. 39, No. 2, pp. 326-356.

Maitlis, S. (2005), "The social processes of organizational sensemaking", Academy of Management Journal, Vol. 48, No. 1, pp. 21-49.

Maitlis, S. and Christianson, M. (2014), "Sensemaking in organizations: Taking stock and moving forward", Academy of Management Annals, Vol. 8, No. 1, pp. 57-125. 
Maitlis, S. and Sonenshein, S. (2010), "Sensemaking in crisis and change: Inspiration and insights from Weick (1988)", Journal of Management Studies, Vol. 47, No. 3, pp. 551580 .

McAdam R., Bititci, U.S., and Galbraith, B. (2017), “Technology alignment and business strategy: a performance measurement and Dynamic Capability perspective", International Journal of Production Research, Vol. 55, No. 23, pp. 7168-7186.

Melnyk, S.A., Bititci, U., Platts, K., Tobias, J., and Andersen, B. (2014), "Is performance measurement and management fit for the future?", Management Accounting Research, Vol. 25, No.2, pp. 173-186.

Melnyk, S.A., Hanson, J.D., and Calantone, R.J. (2010), "Hitting the target... but missing the point: resolving the paradox of strategic transition", Long Range Planning, Vol. 43, No. 4, pp. 555-574.

Merchant, K. and Otley, D. (2020), "Beyond the systems versus package debate", Accounting, Organizations and Society, Vol. 86, pp. 1-7.

Micheli, P. and Manzoni, J.-F., (2010), "Strategic performance measurement: Benefits, limitations, paradoxes", Long Range Planning, Vol. 43, pp. 465-476.

Micheli, P. and Mura, M. (2017), "Executing strategy through comprehensive performance measurement systems", International Journal of Operations \& Production Management, Vol. 37, No. 4, pp. 423-443.

Micheli, P., Mura, M. and Agliati, M. (2011), "Exploring the roles of performance measurement systems in strategy implementation", International Journal of Operations \& Production Management, Vol. 31 No. 10, pp. 1115-1139.

Micheli and Pavlov (2017), "What is performance measurement for? Multiple uses of performance information within organizations", Public Administration, Vol 98, No. 1, pp. $29-45$,

Miles, M., B., and Huberman, A., M. (1994). Qualitative Data Analysis - A Sourcebook of New Methods, Sage, London, UK.

Mirzaei, E.N., Fredriksson, A., and Winroth, M. (2016), "Strategic consensus on manufacturing strategy content", International Journal of Operations \& Production Management, Vol. 36, No. 4, pp. 429-466

Muller, J.Z. (2017), The Tyranny of Metrics, Princeton University Press, Princeton, NJ.

Nudurupati, S.S., Garengo, P. and Bititci, U.S. (2021), "Impact of the changing business environment on performance measurement and management practices", International Journal of Production Economics, Vol. 232, pp. 1-15.

Patriotta, G. (2003), "Sensemaking on the shop floor: Narratives of knowledge in organizations", Journal of Management Studies, Vol. 40, No. 2, pp. 349-375.

Pellinen, J., Teittinen, H. and Järvenpää, M. (2016), "Performance measurement system in the situation of simultaneous vertical and horizontal integration", International Journal of Operations \& Production Management, Vol. 36 No. 10, pp. 1182-1200.

Reinking, J., Arnold, V. and Sutton, S.G. (2020), "Synthesizing enterprise data to strategically align performance: The intentionality of strategy surrogation", International Journal of Accounting Information Systems, Vol. 36, pp. 1-15. 
Rerup, C. and Feldman, M.S. (2011), "Routines as a source of change in organizational schemata: The role of trial-and-error learning", Academy of Management Journal, Vol. 54, No. 3, pp. 577-610.

Robson, C. 2011, Real World Research, Wiley, Hoboken, NJ.

Sandberg, J. and Tsoukas, H. (2015), "Making sense of the sensemaking perspective: Its constituents, limitations, and opportunities for further development", Journal of Organizational Behavior, Vol. 36, No. 1, pp. 6-32.

Smith, M. and Bititci, U. (2017), "Interplay between performance measurement and management, employee engagement and performance", International Journal of Operations \& Production Management, Vol. 37, No. 9, pp. 1207-1228.

Weick, K.E. 1995, Sensemaking in Organizations, Sage, Newbury Park.

Weick, K.E. (1988), "Enacted sensemaking in crisis situations", Journal of Management Studies, Vol. 25, No. 4, pp. 305-317.

Weick, K.E., Sutcliffe, K.M. and Obstfeld, D. (2005), "Organizing and the process of sensemaking", Organization Science, Vol. 16, No. 4, pp. 409-421.

Wouters, M. and Wilderom, C. (2008), "Developing performance-measurement systems as enabling formalization: A longitudinal field study of a logistics department", Accounting, Organizations \& Society, Vol.33, pp. 488-516. 